\title{
Cezary Stępniak
}

Czestochowa University of Technology

e-mail: cezary.stepniak@wz.pcz.pl

ORCID: 0000-0003-4833-6411

\author{
Andrzej Chluski \\ Czestochowa University of Technology \\ e-mail: andrzej.chluski@wz.pcz.pl \\ ORCID: 0000-0001-5310-4469

\section{Zuzana Závadská} \\ College of International Business ISM Slovakia in Presov \\ e-mail: zavadska@ismpo.sk \\ ORCID: 0000-0003-4808-8585
}

\section{THE ROLE OF IT TOOLS SUPPORTING THE USE OF ABSTRACT THINKING \\ IN CREATING INTELLECTUAL CAPITAL PERCEIVED FROM THE PERSPECTIVE OF THE EMPLOYER}

\section{ROLA NARZĘDZI IT WSPIERAJĄCYCH WYKORZYSTANIE ABSTRAKCYJNEGO MYŚLENIA W KREOWANIU KAPITALU INTELEKTUALNEGO POSTRZEGANA Z PERSPEKTYWY PRACODAWCY}

DOI: $10.15611 /$ ie.2019.2.07

JEL Classification: D8, O3

Summary: The article is devoted to the subject of building the intellectual capital of enterprises using the competences of employees regarding their ability to use methods based on abstract thinking. The starting point was the question whether the contemporary employer needs employees who can mainly perform real tasks or are able to apply abstract thinking to solve problems occurring in the enterprise. Against this background, it was also tried to determine what role IT tools can play in this situation. For the purposes of the article, research was carried out with a group of employers who spoke about the needs of their companies in the area of creating their intellectual capital, demand for employee competences in the field of abstract thinking and their creativity, and also to determine what role ICT tools can play.

Keywords: intellectual capital, abstract thinking, information technology. 


\begin{abstract}
Streszczenie: Artykuł poświęcony został tematyce budowy kapitału intelektualnego przedsiębiorstw dzięki wykorzystaniu zdolności pracowników do stosowania metod bazujących na abstrakcyjnym myśleniu. Punktem wyjścia była kwestia, czy współczesnemu pracodawcy bardziej potrzebni są pracownicy, którzy potrafią wykonywać głównie zadania realne, czy też tacy, którzy potrafią stosować abstrakcyjne myślenie do rozwiązywania występujących w przedsiębiorstwie problemów. Na tym tle starano się również określić, jaką rolę mogą odgrywać narzędzia IT w omawianej sytuacji. Na potrzeby artykułu przeprowadzono badania $\mathrm{z}$ grupą pracodawców, którzy wypowiedzieli się na ten temat $\mathrm{z}$ perspektywy swoich przedsiębiorstw.
\end{abstract}

Słowa kluczowe: kapitał intelektualny, myślenie abstrakcyjne, technologie informacyjne.

\title{
1. Introduction
}

Increasing competition in the markets, and the need to constantly adapt to the needs of customers have brought the necessity of the dynamic transformation of business. The frequency of changes does not mean that they are implemented routinely. The problem is not only in the procedure of introducing changes, but first and foremost in determining their direction. The choice of new business lines requires non-standard knowledge and skills to perceive emerging situations from different points of view. The question arises, who in the organization can make a multi-criteria analysis of the existing market conditions? Is this a matter only for the owner or the board or can they be supported by the company's staff?

This article raises the issue of the need to acquire staff with abilities in the area of abstract thinking that allows to strengthen the intellectual capital of the organization. Abstract thinking in this study is treated as the ability to use abstract methods such as: system analysis, spatial analysis, process modeling or mathematical modeling. These skills allow to use abstract structures to describe reality and on this basis look for solutions that are suitable for the market conditions. Nowadays, one of the basic elements shaping intellectual capital is the knowledge and the ability to use abstract thinking methods. Knowledge about these methods itself may turn out to be insufficient, therefore this article raises the issue not only of acquiring the right staff, but also the issue of equipping them with appropriate ICT tools (Information and Communication Technology).

The aim of the article is to analyze the needs of employers in the area of building intellectual capital by employing staff with competence in the knowledge and the application of selected methods based on abstract thinking methods. The research not only analyzed the need to employ staff with these competences, but also the readiness of employers to obtain and share IT tools with them, thanks to which they would be able to use their skills more effectively. 
For the purpose of the study, research was carried out using the method of a directed interview conducted with several employers operating in various industries. The choice of the method was aimed not only at gathering the opinions of employers, but also at getting to know their needs and motivations.

\section{The role and the elements that create intellectual capital}

Economic organizations are created in order to achieve the goals and interests of their members and, to some extent, other stakeholders as well. Depending on the degree of achievement of their goals, economic organizations have a certain value for individual stakeholders. The value of an economic organization is often defined as the sum of the tangible and intangible assets recorded in the accounting books and the intangible assets not included in them, which is the difference between the market price of the enterprise and its accounting value.

In the management sciences, the most important is the value of the organization determined from the point of view of its owners [Rappaport 1999; Itami 1991]. Companies with high development potential, bringing risk-bearing and relatively constant profits, have greater opportunities to create value also for other stakeholders - clients, suppliers and other partners, employees, governmental and political organizations.

Since the middle of the last century, the importance of intangible assets in the total value of an economic organization has been growing. The value of an organization is increasingly determined by its intangible components. However, the real value of a company is its market value, i.e. the sale price of the company in the relevant market. Currently, in most developed countries, the "market price" of wellfunctioning business organizations significantly exceeds their accounting value. This is related to the entry of enterprises into the era of a knowledge-based economy and the widespread use of modern information and communication technologies in human activity [Chluski, Jelonek 2014].

Many research centres have undertaken research on the role, importance, classification and measurement of the above-mentioned intangible assets, due to the need to effectively manage a new type of company resources [Booker et al. 2008; Dobija 2004]. One of the pioneers in this field was L. Edvinsson [1997]. On the basis of research carried out at the Swedish insurance company Skandia, he distinguished the following features of the intellectual capital of an economic organization [Edvinson, Malone 2001]:

- intellectual capital is a very important supplement to traditional financial statements,

- intellectual capital is non-financial in nature (non-monetary directly). However, it is assessed as the difference between the market value of the company and its accounting value,

- intellectual capital has the nature of liabilities, not assets. 


\begin{tabular}{|c|c|c|c|c|c|c|}
\hline 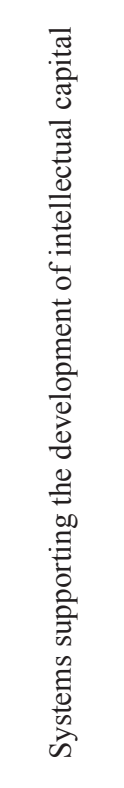 & 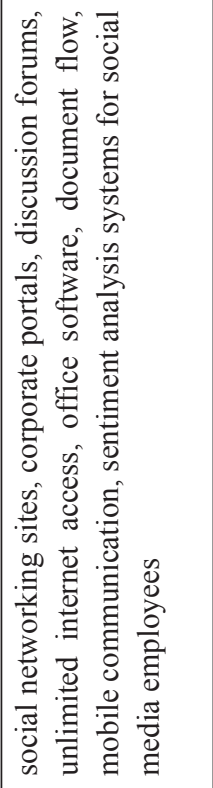 & 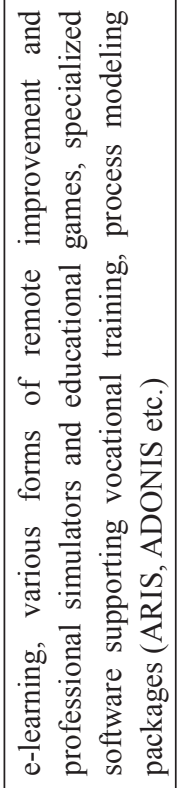 & 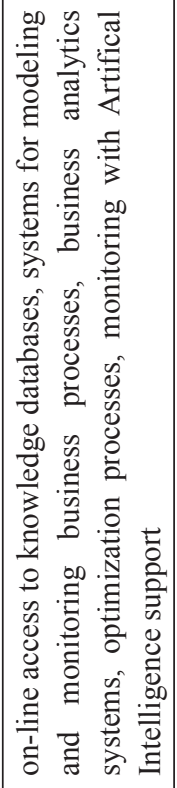 & 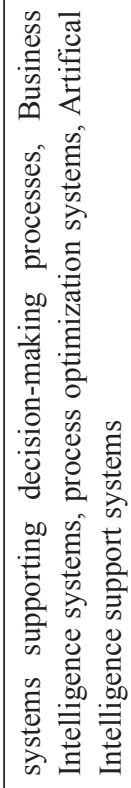 & 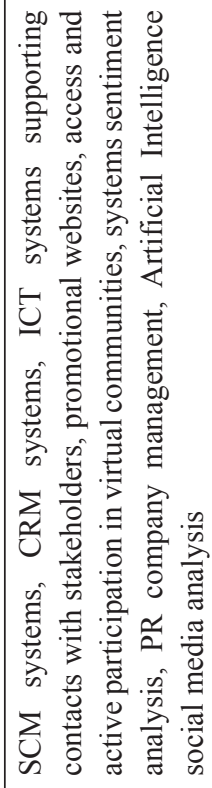 & 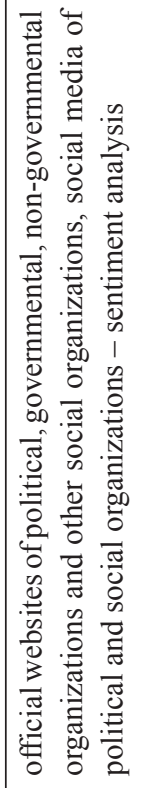 \\
\hline 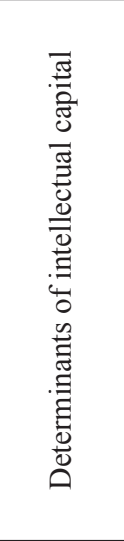 & 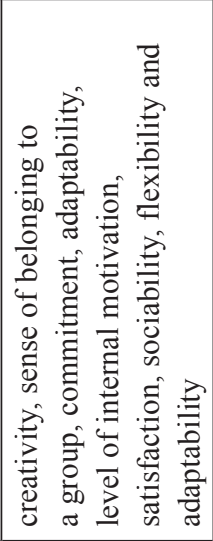 & 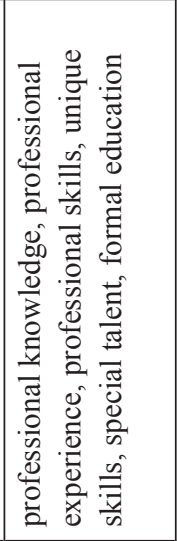 & 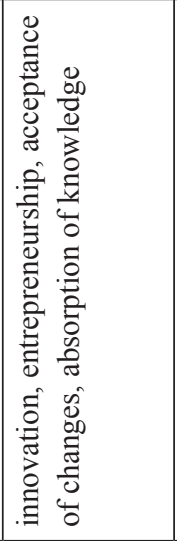 & 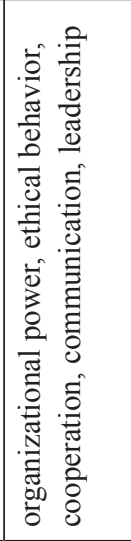 & 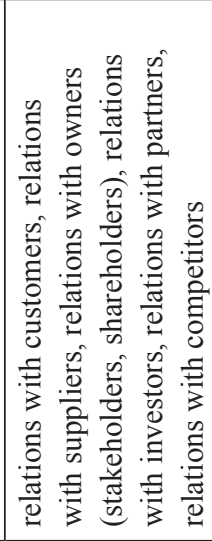 & 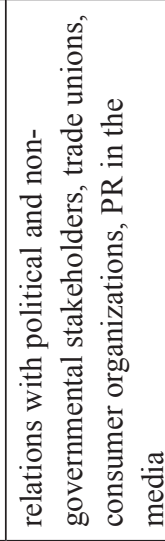 \\
\hline 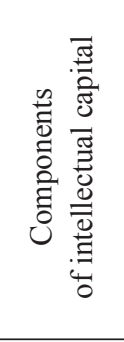 & 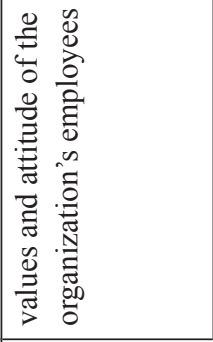 & 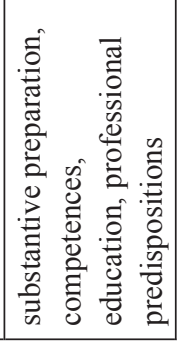 & 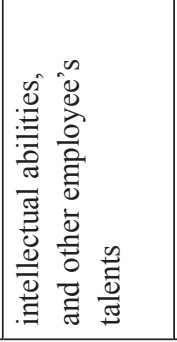 & 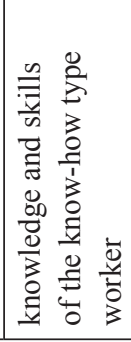 & 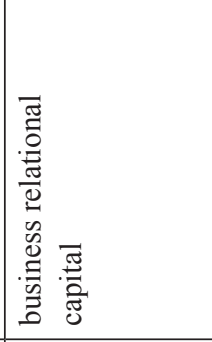 & 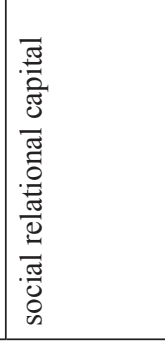 \\
\hline 点兽 & 壳 㞼 & & & & 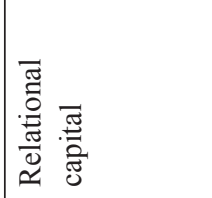 & \\
\hline
\end{tabular}




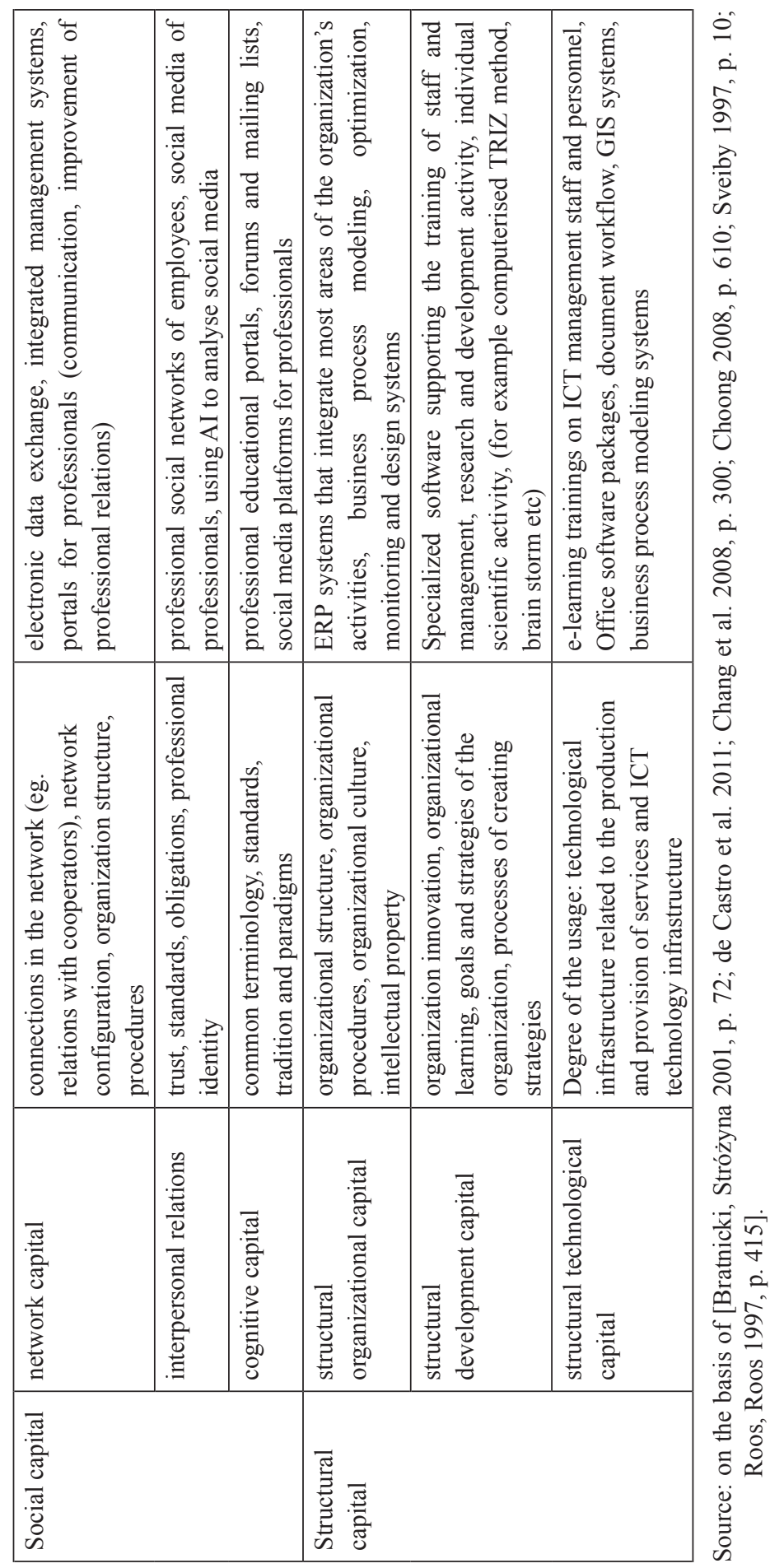


Studies of the essence of intellectual capital have led to the distinction of some of its components. The literature distinguishes its various elements (see, among others [Kaplan, Norton 2004;Tamer et al. 2014].) In this discussion, the classification developed by Bratnicki and Stróżyna was adopted as the original one [Bratnicki, Stróżyna 2001], in which the following elements are distinguished (see Table 1).

The development of artificial intelligence and ICT is currently at such a high level that the use of AI in management of Intellectual Capital can have practical significance for managers. The beginnings of researchers' interest in Artificial Intelligence in the field of artificial learning took place as early as the 1960s. Minsky [1961, p. 8] claims, that "the problems of heuristic programming of making computers solve really difficult problems are divided into five main areas: Search, PatternRecognition, Learning, Planning, and Induction. A computer can do, in a sense, only what it is told to do, but even when we do not know how to solve a certain problem, we may program a machine (computer) to Search through some large space of solution attempts."

The development of information technology and the further development of research on AI allows to foresee the increasing possibilities of using AI in human activity and Intellectual Capital management. Already in the mid-eighties, Minsky [1986] claimed that there should be no significant (qualitative) differences between human thinking processes and the processes of "thinking" machines (computers). People are also actually machines whose brains are composed of many semiautonomous but unintelligent 'agents', and different tasks require the use of different mechanisms. Minsky [1986, p. 308] claims that: "The power of intelligence stems from our vast diversity, not from any single, perfect principle."

In this article, the authors limited themselves to research on abstract human thinking. Possible AI support in the research concerns facilitating access to data, how to present data, searching for new sources of information, i.e. support in creating the premise for making decisions in areas where human-type AI systems cannot be replaced (based on a large database of based on logical inference methods).

In the research, the entire area of creative thinking has been "reserved" for the human brain. This is related to the nature of the research sample. Such abstract thinking processes can be supported by certain heuristic methods such as brainstorming, the Russian TRIZ method and others, using ICT capabilities and those based on the experience of specific industries and companies.

Assuming the rationality of employers (owners or managers of enterprises), they should care about building intellectual capital which, as stated, promotes both increasing the value of the company, and also facilitates management, among other things, due to the fact that the staff can solve emerging problems by themselves. 


\section{The use of abstract thinking skills in business management}

The ability to solve emerging problems, especially non-standard ones, requires an unconventional approach. In this case, the ability to use abstract thinking may be a useful ability.

Abstract thinking is the ability to think about objects, principles, and ideas that are not physically present. It is related to symbolic thinking, which is the symbol for the object or idea [Farlex Partrer... 2012], and allows to conduct speculations using methods that enable to describe selected sections of reality using abstract concepts, logical constructions, description methods or other forms of representation. In effect the ability of abstract thinking can be used at different management levels and roles. The demand for thinking abstractly can be further diversified by the area of the organization in which the person operates. Commons and Ross [2008] argue that about $70 \%$ of adults in the developed countries of the West use formal and postformal thinking in their professional work, an advanced type of abstract thinking.

Abstract thinking can be used in various areas of human activity. With its development, depending on the field of socio-economic life, various methods have been developed that could support these skills. In these considerations, four methods [Graham 2018; Brocke, Mendling 2017; Grzybowski 2017; Fisher, Wang 2011; Turek, Stępniak 2014] have been analyzed that can be used in abstract thinking. These are:

- system analysis,

- spatial analysis,

- business process modeling,

- mathematical models.

The choice of the abovementioned methods supporting abstract thinking resulted from the analysis of curricula at higher education, above all management departments, preparing future top managers and mid-level managers. In this case it is important not only to know the selected methods based on abstract thinking, but also the ability to use them under specific conditions. From the point of view of employers, the use of these skills can take place under different circumstances. For research purposes, the following were selected:

- implementation of new technologies,

- searching for new areas of activity,

- reorganization of the company's operation,

- searching for a market determinant,

- building the position of the company's brand.

It was assumed that employers mainly hire employees to carry out standard tasks. Skills in using abstract thinking methods are considered a useful addition [Zmich et al. 2018]. Therefore, the question arises of whether employers have prepared an appropriate infrastructure for them in the form of the suitable ICT tools to use these skills [Stępniak, Jelonek 2014]. 
The new cultural and social phenomena require virtual space for which the fundamentals are constituted by ICT technologies [Jelonek 2018] and which strengthen the potential and effectiveness of the abstract thinking of business organization members. This applies to the use of all Information Systems available in the company [Jelonek et al. 2013] as a source of data and specialized, dedicated IT tools supporting the abstract thinking of employees. This type of ITC support depends on the specificity of the industry, the company's strategy, the way and methods of management and it applies to a different extent to all types of intellectual capital.

\section{Applied research methodology}

The presented research was preliminary, and in a sense probing. The starting point for the described research was to conduct a survey among potential respondents as to what they perceive by such terms as intellectual capital and its components, and abstract thinking. Generally, as a result of the conducted survey, it can be assumed that both concepts are known, however most of the respondents probably did not think about whether they could be important in their business. Therefore, it can be assumed that apart from scientific results, the research also had some promotional and, in some cases, educational goals.

The aim of the research was to determine what competencies employers expect from their employees. It should be stated that in these studies employees were treated as a whole, without distinguishing what specific positions they work in. Either employees who perform standard tasks are primarily needed or employers are interested in the creativity of their employees and skills in the field of various types of tools that can affect the smooth functioning of the organization.

In this way, intellectual capital, skills in applying abstract thinking methods and what ICT tools are used for this purpose were recognized as the key research issues. As stated above, taking into account the specificity of the subject of the research and the fact that they are of a preliminary nature, one of the direct research methods was selected, therefore a directed interview technique was chosen to work with the respondent. The advantage of this method is the possibility of being in direct contact with the respondent, thanks to which it is possible to explain the context of particular concepts discussed during the interview. Unfortunately, its disadvantage is its timeconsuming nature, and thus it was decided that interviews with respondents would be case studies. To this end, several respondents were selected who represent various branches of economic activity and different sizes of organization. The talks were conducted with the owners of companies (in the case of small and medium-sized business entities) and representatives of top management or middle-level management. The scenario includes issues regarding the suitability of competences in the field of abstract thinking, which methods may be useful and in which areas of activity they are used. Next, attention was paid to what elements of intellectual 
capital may affect competences in the field of abstract thinking. Elements of intellectual capital were taken from the Bratnicki and Stróżyna model [Bratnicki, Stróżyna 2001]. The interview was concluded with questions about ICT tools that are used in enterprises and which can support the use of methods of abstract thinking.

The obtained material was analyzed mainly due to the qualitative data obtained from the interviews. Quantitative data are mainly complementary, and during the interviews, quantitative data were used to illustrate the issues that were mentioned more fully. The factual material collected during the research has demonstrative nature. On one hand, it allows to present the research terminology to respondents, and on the other, it allows to orientate oneself in the trends that occur, so that one can conduct wider research on a much larger research group in the future.

\section{Research results}

As mentioned, the research prepared for this study was preliminary. The prepared scenario became the basis for conducting interviews with representatives of eight enterprises. These were diversified enterprises both in terms of employment size and the industries represented. The surveyed enterprises operate, among others, in the metal, ecological, gastronomy and IT industries. Interviews were conducted with the owners of companies or members of senior management.

The modern functioning of enterprises is increasingly dependent on the use of IT tools. In this research, ICT has assumed the role of a kind of verifier of declarations on the need of hiring employees with skills in abstract thinking submitted by respondents.

The starting point in interviews was about the types of competencies required of a potential employee. This was about whether employers are interested in real competences that are specific to a given position or whether skills in using abstract thinking methods are crucial as well. This issue was treated as a form of slider between 0 and $100 \%$. The research results show that employers mainly care about real competences. In general, the slider of needs, in terms of the ability to use the methods of abstract thinking, did not exceed $20 \%$, mostly it was $10 \%$. Although it was also stated that in some part, these competences are not required for line (worker) positions. However, when hiring for managerial positions, the demand for skills in the use of abstract thinking methods increases, and in this case the mentioned slider reached even up to $50 \%$.

The complementary question about needs in the area of the abilities of using the abstract thinking tools was that of whether employees should be creative. The answers oscillated between the selected ones and the majority. In other words, the issue of creativity was associated with selected positions, mainly managerial and analytical. In this case, the needs slider oscillated between 30\% in smaller enterprises and up to $80 \%$ in an innovation-oriented company. 
The results presented above are confirmed by the analysis of areas which have an impact on shaping intellectual capital. In this case, the greatest emphasis on the creativity of employees was placed in the area of implementing new technologies and building the position of the company's brand. In both of these areas, the slider exceeded $50 \%$, while in other areas it was between $35 \%$ to $45 \%$. These included areas such as the reorganization of the company's operation, the search for a market determinant and the search for new business areas.

The following part of the interview concerned the sense of creating relational capital. Using the Bratnicki and Stróżyna models, the authors tried to determine which elements are the most important for employers. According to the respondents' recommendations, human capital is the most important, where one of the basic values is the knowledge and creativity of employees. As part of the remaining elements of the intellectual capital of enterprises, the respondents considered the most important cognitive capital as part of social capital, covering issues such as common terminology, standards and norms, tradition and paradigms. It can therefore be assumed that the most important elements of intellectual capital were the employees' abilities, which are largely connected with abilities in the field of abstract thinking.

The next section of the interview concerned the usefulness of specific methods based on abstract thinking. As mentioned above, the research focused mainly on four methods, i.e. system analysis, spatial analysis, business process modeling and mathematical and statistical models.

The modeling of business processes was considered the most useful, especially in enterprises in which a process approach was implemented or where this possibility is considered. The method of system analysis used for the overall assessment of the company's situation or selected areas of its activity is also considered useful. Less importance was given to mathematical and statistical methods (due to lack of knowledge in this field, or skills in their application) and spatial analysis (in this case, mainly geographic, e.g. in logistics, or physical aspects were concernedrelated to planning site development or planning of construction of technological lines.) Generally, it was considered that these methods are the domain of selected employees and only this group is de facto involved in their use.

It can be assumed that the abilities of abstract thinking are useful, although the management boards of enterprises prefer to control them. These abilities are valued in solving ad hoc problems, while they are less expected to implement innovations. Innovation issues are rather left to managers' competence to maintain corporate governance.

The results presented so far were based on a kind of declaration of needs in the use of abstract thinking methods. A certain kind of empirical verification is the question of whether the researched methods have support in the form of ICT tools. As is known, the widespread use of ICT tools can mean a kind of determinant whether the use of specific methods is strictly planned or is the result of the company's 
current development in a specific field. Prior to the research, an analysis of ICT tools supporting the research methods based on abstract thinking was made. These methods were presented to respondents and the scope of their applications was checked.

Data on the use of ICT tools indicate that in the majority of the surveyed enterprises, the application of abstract thinking methods is not supported on a planned basis. Most ICT tools which support these methods are used in the enterprise for other purposes.

The most frequently used ICT tools are Office Packages, then tools used for e-learning, followed by tools used to model business processes, mathematical and statistical tools, a package that enables drawing mind maps and GIS software. In principle, all of the featured tools have a different application in the company, hence it is difficult to put forward a thesis that they were used primarily to support methods based on abstract thinking. On the other hand, the obtained results would confirm the respondents' indications about the usefulness of the mentioned methods and the related competences at the level of $10 \%$ to $20 \%$, additionally referring to selected employees.

In the interviews' summary, a question on the usefulness of employee abilities in the field of abstract thinking and ICT tools used for this purpose was asked once again. In general, the majority of respondents confirmed the usefulness of employees with these competences, but above all they are interested in their competences regarding real activities. This is similar to ICT tools that today provide the support for the use of these methods and is limited to those already applied in the company.

\section{Conclusion}

Referring to the purpose of the article, this was to examine the needs of employers in the area of building intellectual capital of companies through the use of employees' abilities in the area of abstract thinking based methods. Efforts were also made to determine the role IT tools could play in this field. As a result of the research, several conclusions can be drawn.

First of all, most employers are interested in the fact that employees have the competences tested, however, so far they distance them mainly from their real tasks.

Secondly, the demand for the use of abstract thinking competences arises mainly when the emerging non-standard problems have to be solved. This is about both the strategic, tactical and operational problems. One kind of exception is the question of competence in the field of business process modeling.

Thirdly, most companies do not use specialized ICT tools to support the use of abstract thinking methods. The applied ICT tools are usually also used in other areas of the company's activity.

To sum up, it can be stated that enterprises are interested in the development of their intellectual capital. They declare their willingness to use the competences 
tested, but their main effort is directed to the implementation of their current tasks. On the other hand, the use of the examined competences takes place on the occasion of solving problems arising from the company's operations. The role of ICT tools is in a way the result of the need to use these competences. Their use occurs when specific needs arise. Undoubtedly, many enterprises that will wish to build their intellectual capital based on abstract thinking methods will also have to plan the development of their ICT base in this field. In future research on this subject, the authors intend to improve their methodology of research and expand the scope, with particular regard to the level of strategic management.

\section{References}

Booker L., Bontis N., Serenko A., 2008, The relevance of knowledge management and intellectual capital research, Knowledge and Process Management, vol. 15, no. 4, pp. 235-246.

Bratnicki M., Strużyna J., 2001, Przedsiębiorczość i kapitat intelektualny, Wyd. AE w Katowicach, Katowice.

Brocke vom J., Mendling J. (eds.), 2017, Business Process Management Cases: Digital Innovation and Business Transformation in Practice, Springer, Cham.

Castro de G.M., Lopez J.E.N., Muina F.E.G., Saez P.L., 2011, A new model to measure and manage intelectual capital, www2.warwick.ac.uk/fac/soc/wbs/conf/olkc/archive/oklc5/papers/k-4_decastro. pdf (09.11.2018).

Chang S., Chen S., Lai J., 2008, The effect of alliance experience and intellectual capital on the value creation of international strategic alliances, Omega, The International Journal of Management Science, vol. 36 .

Chluski A., Jelonek D., 2014, Technological context of healthcare entity intangible asset management, Online Journal of Applied Knowledge Management, vol. 2, iss. 2, pp. 120-131.

Choong K.K., 2008, Intellectual capital: Definitions, categorization and reporting models, Journal of Intellectual Capital, vol. 9, no. 4.

Commons M.R., Ross S.N., 2008, What postformal thought is, and why it matters, The Journal of New Paradigm Research, vol. 64, iss. 5-7.

Dobija D., 2004, Pomiar i sprawozdawczość kapitalu intelektualnego w organizacjach działajacych $w$,nowej gospodarce”, Organizacja i Kierowanie, no. 1(115).

Edvinsson L., 1997, Developing intellectual capital in Skandia, Long Range Planning, vol. 30, no. 3.

Edvinsson L., Malone M.S., 2001, Kapitat intelektualny, PWN, Warszawa.

Farlex Partner Medical Dictionary, 2012, https://medical-dictionary.thefreedictionary.com /abstract+ thinking (07.10.2018).

Fischer M.M., Wang J., 2011, Spatial Data Analysis: Models, Methods and Techniques (SpringerBriefs in Regional Science), Springer.

Graham J., 2018, System Analysis in Business, Routledge, Tylor \& Francis Group.

Grzybowski A.Z., 2017, Selected Topics in Contemporary Mathematical Modeling, Publishing Office of Czestochowa University of Technology, Czestochowa.

Itami H., 1991, Mobilizing Invisible Assets, Harvard University Press, Cambridge, MA.

Jelonek D., Stępniak C., Turek T., Ziora L., 2013, The Influence of Virtualization of Resources Acquisition Processes on Enterprises Competitiveness, ICETE 2013. 10th International Joint Conference on e-Business and Telecommunications. Proceedings. 29-31 July, Reykiavik, Iceland. 
Jelonek D., 2018, Systemy informatyczne zarzqdzania przedsiębiorstwem. Perspektywy strategii i tworzenia wartości, PWE, Warszawa.

Kaplan R.S., Norton D.P., 2004, Strategy Maps: Converting Intangible Assets into Tangible Outcomes, Harvard Business School Press, Boston.

Minsky M.L., 1961, Steps toward Artificial Intelligence, Proceedings of the IRE, 49(1), pp. 8-30.

Minsky M.L., 1986, Society of Mind, Simon \&Schuster, New York.

Rappaport A., 1999, Wartość dla akcjonariuszy. Poradnik menedżera i inwestora, WIG-Press, Warszawa.

Roos J., Roos G., 1997, Measuring your company's intellectual performance, Long Range Planning, vol. 30 , no. 3 .

Stępniak C., Jelonek D., 2014, Evaluation of the usefulness of abstract thinking as a manager's competence, Polish Journal of Management Studies, vol. 9.

Sveiby K.E., 1997, The New Organizational Wealth: Managing and Measuring Knowledge-based Assets, Barrett-Koehler Publishers, San Francisco.

Tamer I., Dereli B., Saglam M., 2014, Unorthodox forms of capital in organizations: positive psychological capital, intellectual capital and social capital, Procedia - Social and Behavioral Sciences, vol. 152 , pp. 963-972.

Turek T., Stępniak C., 2014, Integration of spatial information resources on the example of utility companies in Częstochowa region, Online Journal of Applied Knowledge Management, vol. 2, iss. 2.

Zmich L., Groza M., Schaefers T., Groza M.D., 2018, Abstract Thinking and Salesperson Entrepreneurial Orientation: An Abstract, [in:] N. Krey, P. Rossi (eds.), Boundary Blurred: A Seamless Customer Experience in Virtual and Real Spaces. AMSAC 2018. Developments in Marketing Science: Proceedings of the Academy of Marketing Science, Springer, Cham. 